\title{
Research Journal of Animal and Veterinary Sciences
}

2018 September; $10(3)$ : pages: $1-7$ DOI: 10.22587/rjavs.2018.10.3.1

\section{Influence of probiotic bacteria isolated from camels' milk on the physicochemical properties of camels' milk stirred yoghurt}

\author{
Marwa H. El-Gendy \\ Animal of Breeding Department, Animal Production Division, Desert Research Center, Cairo, Egypt \\ *Corresponding Author: \\ Marwa H. El-Gendy \\ Animal of Breeding Department, Animal Production Division, Desert Research Center, Cairo, Egypt \\ Email: marwaelgendy616@gmail.com
}

Received date: 18 January Accepted date 21 February Online date: 10 September 2018

Copyright: (C) 2018 Marwa H. El-Gendy, This is an open-access article distributed under the terms of the Creative Commons Attribution License, which permits unrestricted use, distribution, and reproduction in any medium, provided the original author and source are credited.

\begin{abstract}
The objectives of this study were to evaluate the physicochemical properties of camels' milk stirred yoghurt produced from probiotic bacterial strains isolated from camels' milk. After isolation and identification of the lactic acid bacterial strains (LAB) and evaluation of their probiotic properties, they were examined, for some growth and technological properties. The selected isolates were Lb. plantarum, Lb. fermentum, Bifi. animalis, Lb. acidophilus, and Lb. rhamnosus. These strains were used as starter culture in the manufacture of liquid fermented camels' milk like-stirred yoghurt. The traditional yoghurt starter was used as control. The results show that all selected isolates had the ability to produce exopolysaccharide (EPS), diacetyl and proteolytic activity. Their ability to produce biomass and acidity varied between the strains. The results revealed that there were significantly affected chemical composition, microbiological count, $\mathrm{pH}$, viscosity and water holding capacity (\%) of nonfat fermented camel milk drink during storage except ash (\%). It was found that $L b$. acidophilus, $L b$. plantarum and Lb. rhamnosus were the closest to the stirred yogurt in terms of appearance, viscosity and flavor on Bifi. animalis and $L b$. fermentum. This study reveals that the LAB isolates from camel milk has a high ability to apply as probiotics, with high production of EPS, survived at low pH, and inhibit some food pathogens, from which it can make them promising candidates to produce functional food with potential health benefits
\end{abstract}

Key words: Camel milk, probiotic, exopolysaccharide

\section{INTRODUCTION}

Lactic acid bacteria (LAB) are considered the most important group of bacteria used in the food industry; it's contained number of bacterial genera such as Enterococcus Lactococcus, lactobacillus, leuconostoc, pediococcus and streptococcus. From the point of safety view, most of LAB used in food industry are generally regarded as safe (GRAS)

LAB have many advantages, such as probiotics, the ability to rival bacteria causing the disease (Likotrafiti and Rhoades, 2016), as well as the production of antimicrobial agents such as acetic acid, ethanol, hydrogen peroxide and 2-(2-1 mino-1hydroxyethoxy) ethyl 2-methylpropanoate, which inhibit the growth of many food spoilage and pathogenic bacteria (Lin and Pan, 2017). In addition, they can be used as food preservatives by producing bacteriocins (Silva et al., 2018). They also had the ability to develop flavor in different foods (Chen et al., 2017). Besides acting as exopolysaccharides and several enzymes (Salazar et al., 2016). LAB used as starter cultures to ferment many foods and beverages.

From the above it is clear that fermented foods have a positive effect on human health. Therefore, fermented milk using one or more strains has a major role in supplying the human body with many essential biological components such as vitamins, enzymes, exopolysaccharides, bacteriocins and bioactive peptides (Patel et al., 2013).

The camel milk consumption used according to traditional methods in the form of raw or fermented, in the arid and semiarid regions in the Africa and Asian countries (Abera et al., 2016). Many researchers indicated the importance of the chemical composition of camel milk. The camel milk fat contains high polyunsaturated fatty acids. It also contains bioactive peptides have a beneficial effect on immunomodulatory activities, antioxidative activities (Parrella et al. 2012; Solieri et al. 2015) In addition, camel milk was free from $\beta$-lactoglobulin which cause milk allergies (Mertin et al., 2001). Abushelaibi et al (2017) explained that camel milk an excellent source of LAB and can be isolated with high probiotic potential Shihata and Sah (2000) has indicated that probiotics (Lb. acidophilus and Bifidobacteria sp) grow slowly in milk compared with yogurt bacteria (Lactobacillus delebrukii subsp. bulgaricus and Streptococcns thermophilus) due to its low ability to proteolytic activity. This is illustrated with what was said by Jumah et al. (2001) that some problems occur in camel milk during the fermentation, such that the viscosity of the product 
does not change during gelation. Because LAB have the ability to produce EPS which improve the rheological properties of the fermented product. Therefore, this study sought to determine the physico-chemical properties of camels' milk stirred yoghurt made using some lactic acid bacteria isolated from raw camel's milk.

\section{MATERIAL AND METHODS}

\section{Sampling}

Milk samples were collected from camels from North West Coast Zone and south of Egypt. The samples were immediately cooled and transported to the laboratory and analyzed upon arrival. The chemical composition of raw camel's milk is shown in table 1.

Table 1: Chemical composition of raw camel's milk

\begin{tabular}{|c|c|c|c|c|c|c|}
\hline Camel's milk & \multicolumn{7}{|c|}{ Milk constituents } \\
\cline { 2 - 8 } sample source & $\mathrm{pH}$ & Fat \% & Protein \% & lactose\% & salt \% & SNF \\
\hline North & 6.6 & 3.3 & 4.7 & 7.0 & 1.0 & 12.19 \\
\hline south & 6.7 & 3.0 & 4.5 & 5.5 & .98 & 11.98 \\
\hline
\end{tabular}

\section{Isolation and identification of strains}

Isolation and identification of Lactic Acid Bacterial strains from camel's milk has been produced in the previous work (Mohammed et al., 2018). Table 2 shows the strains selected for this study in terms of isolation, pre-identification and identification.

\section{Growth and technological attitude \\ Biomass production}

Strains were sub-cultured on MRS broth; $100 \mathrm{~mL}$ of the medium was inoculated with $10 \%$ of the active culture. Bacterial growth was monitored by measuring the optical density at $600 \mathrm{~nm}\left(\mathrm{OD}_{600}\right)$ during $6 \mathrm{~h}$. The difference between the initial OD and the OD at which cells were collected $(\Delta \mathrm{OD})$ was taken as an indicator of growth. At the early stationary phase, $30 \mathrm{~mL}$ of culture was harvested by centrifugation at $5000 \mathrm{x}$ g for $30 \mathrm{~min}$ at $4{ }^{\circ} \mathrm{C}$. The dry weight was determined after drying the pellet at $105{ }^{\circ} \mathrm{C}$ for $3 \mathrm{~h}$. The remaining $70 \mathrm{~mL}$ was used to study the separation of biomass by centrifugation and measurement the $\mathrm{OD}_{600}$ of supernatant (Fguiri et al. 2016).

Table 2: Some characters of the lactic acid bacterial isolates*.

\begin{tabular}{|c|c|c|c|c|c|c|c|}
\hline \multirow{2}{*}{$\begin{array}{c}\text { Strain } \\
\text { No. }\end{array}$} & \multirow{2}{*}{$\begin{array}{c}\text { Gram } \\
\text { stain }\end{array}$} & \multirow[t]{2}{*}{ Catalase } & \multicolumn{2}{|c|}{ Growth } & \multirow[t]{2}{*}{$\mathrm{CO}_{2}$ production } & \multirow[t]{2}{*}{ Pre-identification } & \multirow[t]{2}{*}{ identification } \\
\hline & & & $10^{\circ} \mathrm{C}$ & $45^{\circ} \mathrm{C}$ & & & \\
\hline $14 \mathrm{CM}$ & + & - & - & + & - & G.A & $\begin{array}{l}\text { Bifdobacterium } \\
\text { animalis }\end{array}$ \\
\hline $17 \mathrm{CM}$ & + & - & - & + & + & G.C & Lb.fermentum \\
\hline $25 \mathrm{CM}$ & + & - & + & + & - & GB & Lb. rhamnosus \\
\hline $31 \mathrm{CM}$ & + & - & - & + & - & G.B & Lb. acidophilus \\
\hline $40 \mathrm{CM}$ & + & - & + & - & - & G.B & Lb. plantarum \\
\hline
\end{tabular}

*(Mohammed et al., 2018)

\section{Exopolysaccharide production}

The cultures were streaked on modified MRS medium and incubated at the optimum growth temperature for $24 \mathrm{~h}$ then tested for slime formation using the inoculated loop method (Knoshaug et al. 2000). Formed colonies were dragged up using a metal loop, and the strains were considered positive slimy producers if the length of slime was above $1.5 \mathrm{~mm}$. Bacterial culture was mixed with India ink and spread out in a thin film on a slide. After air drying bacteria appear as lighter bodies in the midst of a blue-black background because ink and dye particles cannot penetrate either the bacterial cell or its capsule (Ayad et al. 2004).

\section{Evaluation of proteolytic activity}

To evaluate proteolytic activity, LAB isolates were plated on milk agar. The milk agar was prepared by adding $1 \%$ skim milk powder to Plate Count Agar (de Almeida Júnior et al., 2015). The plates were incubated at $7{ }^{\circ} \mathrm{C} / 10$ days and $37{ }^{\circ} \mathrm{C} / 48 \mathrm{~h}$. The transparent halo-forming colonies were considered positive for proteolytic activity.

\section{Diacetyl production}

Diacetyl production was determined according to de Almeida Júnior et al. (2015) with modification the growth of the strains in the skimmed camel milk. The pellet was suspended in peptone water and inoculated $(1 \%(\mathrm{w} / \mathrm{v})) \mathrm{in} 10 \mathrm{~mL}$ skimmed 
camel milk and incubated at $30{ }^{\circ} \mathrm{C}$ for $24 \mathrm{~h}$. Then, $1 \mathrm{~mL}$ of culture was added to $0.5 \mathrm{~mL}$ of $\alpha$-naphthol solution ( $1 \%$ (w/v)) and $\mathrm{KOH}(16 \%(\mathrm{w} / \mathrm{v}))$ followed by incubation at $37{ }^{\circ} \mathrm{C}$ for $10 \mathrm{~min}$. The production of diacetyl was indicated by a formation of a red ring in the tubes. The tests were conducted in duplicate.

\section{Acidification activity}

Acidification activity was measured according to Ayad et al. (2004) by the change in $\mathrm{pH}(\Delta \mathrm{pH})$ during time. Fifty milliliters of reconstituted skim milk was inoculated with $2 \%$ of culture at early stationary growth phase and incubated at appropriate incubation temperature. The $\mathrm{pH}$ was followed at $0,2,4$, and $6 \mathrm{~h}$ using a $\mathrm{pH}$ meter. The acidification rate was calculated as $\Delta \mathrm{pH} ; \Delta \mathrm{pH}=\mathrm{pH}$ at time $-\mathrm{pH}$ zero time. The cultures were considered as fast, medium or slow acidifying when a $\Delta \mathrm{pH}$ of $0.4 \mathrm{U}$ was achieved after $3,3-5$ and $>5 \mathrm{~h}$, respectively

\section{Production of fermented camels' milk like stirred yoghurt.}

The preparation and fermentation of camels' milk was performed according to the method of Ayyash et al. (2017). Skim camels' milk was pasteurized at $95^{\circ} \mathrm{C}$ for $30 \mathrm{~min}$ followed by cooling at $4{ }^{\circ} \mathrm{C}$. Then, inoculated with $2 \%$ from each of isolated strain $\left(\sim 9.0 \log _{10} \mathrm{cfu} / \mathrm{mL}\right)$ and compared to commercial freeze-dried DVS yoghurt starter of CH-1 (containing of Lactobacillus delbrueckii ssp. bulgaricus and Streptococcus thermophilus) as which produced by Chr. Hansen Laboratory Copenhagen, Denmark. Inoculated camels' milk was incubated at $37^{\circ} \mathrm{C}$ for $24 \mathrm{~h}$. Fermented camels' milk was stored at $4^{\circ} \mathrm{C}$.

Chemical, physicochemical analysis and bacterial enumeration

Skim fermented camels' milk was analyzed for total solids, moisture content, total nitrogen, lactose and ash contents; as well as $\mathrm{pH}$ values. Water holding capacity measured as described Abdelmoneim et al. (2016). The apparent viscosity of samples was measured at $22{ }^{\circ} \mathrm{C}$ using a Brook field digital viscometer (Brookfield Engineering Laboratory Inc., Stoughton, MA, USA) Model DV- II with a helipath stand mounted with a spindle SC-4, as formerly described by Barakat and Hassan (2017). All apparent viscosity measurements were recorded as $\mathrm{mPa}$.s. Bacterial enumeration of LAB isolates were counted using M17 agar and incubated aerobically at $37{ }^{\circ} \mathrm{C}$ for $48 \mathrm{~h}$. Changes in $\mathrm{pH}$, the viability of bacteria, viscosity and water holding capacity of fermented camels' milk were determined at every week during the storage period. The chemical composition was determined in fresh day only.

\section{Sensory evaluation}

Sensory evaluation of the product was carried for flavour and texture by trained panelists consisting (Ayad et al. 2004). Sensory evaluation of the milk cultures was carried for flavour and texture by a trained panelists consisting of at least 10 judges. Statistical Analysis

Data of the experimental was analyzed by the General Linear Model (GLM) procedure of SAS (2004)

\section{Growth and technological aptitude}

\section{RESULTS AND DISCUSSION}

Preferably in the selection of starter in the industry to have the ability to reach the largest biomass in the fermentation time. The division of biomass according to Ayad et al. (2004) into three groups: the best when biomass was $\geq 1.30 \mathrm{mg} / \mathrm{L}$, fair when the biomass ranged from 0.6 to $1.29 \mathrm{mg} / \mathrm{L}$ and poor performers when the biomass was $<0.6 \mathrm{mg} / \mathrm{L}$. Lb. rhamnosus $25 \mathrm{CM}$ and $L b$. plantarum 40CM strains were characterized by high growth rate followed by Bifdobacterium animalis 14CM and Lb. acidophilus $31 \mathrm{CM}$ strains that were medium-growth rate while $\mathrm{Lb}$. fermentum $17 \mathrm{CM}$ was low in growth rate, affecting biomass. The production of low amounts of biomass may be due to its ability to produce of exopolysaccharides that reduce the separation of bacterial cells from the culture medium and this was evident in the Lb. fermentum 17CM strain. This result is consistent with Fguiri et al. (2016). These strains have been used to study their effect in the production of camels' milk stirred yoghurt. The maximum growth rate $(\mu \max )$ of strains was estimated during their growth in MRS broth. The maximum specific growth rate at 6 $\mathrm{h}(\mu \max )$ varied between 0.154 and $0.665 \mathrm{~h}^{-1}$ (Table 3$)$.

Table 3: Growth characteristics, ESP, proteolytic activity and diacetyl production of the starter

\begin{tabular}{|c|c|c|c|c|c|c|c|c|}
\hline & strains & $\Delta \mathrm{OD}_{600}$ & $\begin{array}{c}\text { Biomass } \\
(\mathrm{g} / \mathrm{L})\end{array}$ & $\begin{array}{c}\mathrm{OD}_{600} \\
\text { supernatant }\end{array}$ & $\begin{array}{c}\mu \mathrm{max}^{-1} \\
\left(\mathrm{~h}^{-1}\right)\end{array}$ & ESP & $\begin{array}{c}\text { proteolytic } \\
\text { activity }\end{array}$ & Diacetyl \\
\hline Lb. plantarum & $40 \mathrm{CM}$ & 1.566 & 0.984 & 0.015 & 0.655 & ++ & ++ & ++ \\
\hline Lb. fermentum & $17 \mathrm{CM}$ & 0.519 & 0.968 & 0.053 & 0.154 & +++ & ++ & ++ \\
\hline Bifi. animalis & $14 \mathrm{CM}$ & 0.757 & 0.975 & 0.039 & 0.270 & +++ & ++ & ++ \\
\hline Lb. acidophilus & $31 \mathrm{CM}$ & 0.867 & 0.979 & 0.029 & 0.310 & ++ & ++ & ++ \\
\hline Lb. rhamnosus & $25 \mathrm{CM}$ & 1.668 & 0.991 & 0.006 & 0.665 & ++ & ++ & ++ \\
\hline
\end{tabular}

The microscopic results of EPS production showed that all strains produced EPS but its production capacity was uneven (Table 3). Where the production of EPS in both Lb. fermentum 17CM and Bifi. animalis 14CM was more than Lb. plantarum 40CM, Lb. acidophilus 31CM and Lb. rhamnosus 25CM. This may be due to culture and fermentation conditions of acidity, temperature and media compounds (de Almeida Júnior et al. 2015). These strains can be of interest because some of them capable of producing slime (EPS) which can be used in the production of fermented milk. Due to EPS ability to bind to casein micelles 
Citation: Marwa H. El-Gendy.2018. Influence of probiotic bacteria isolated from camels' milk on the physicochemical properties of camels' milk stirred yoghurt Res. J. Anim. \& Vet. Sci.10 (3): pages: 1-7. DOI: 10.22587/rjavs.2018.10.3.1.

and reduce the syneresis, it improves the fermented milk product by increasing the viscosity (Vuyst et al. 2003). Angmo et al (2016) and Ayyash et al. (2018) have indicated the ability of lactic acid bacteria isolated from camel's milk to produce EPS

All strains showed medium production of diacetyl. It contributes greatly to the flavor, which is an important advantage in the dairy manufacture (Rincon-Delgadillo et al., 2012).

Proteolytic activity is an indicator of the presence of bioactive compounds with high health benefits in the fermented product (Hailu et al., 2016). Table (3) shows proteolytic activity tests. All strains showed a positive result of proteolytic activity. This result in agreement with de Almeida Júnior et al. (2015) which stated that proteolytic LAB contributes in the development of flavor in fermented milk products.

Acidification activity

One of the conditions for selecting starter culture for lactic fermentation was its ability to produce acidity. It was observed that the $\mathrm{pH}$ development were fast $(\Delta \mathrm{pH} \geq 0.3 \mathrm{U})$ for the strains studied within $6 \mathrm{~h}$, and indicating their ability to have antimicrobial activity. Because the first step in the dairy manufacture is the ability to rapid decline in $\mathrm{pH}$ so as to prevent unwanted microflora and rapid coagulation. This result agree with Ayad et al. (2004). The results indicated that Lb. fermentum 17CM and Lb. acidophilus 31CM had higher acidification activity. While, Lb. plantraum, Bifi. animalis 14CM and Lb. rhamnosus 25CM showed a slow acidification rate (Fig. 1).

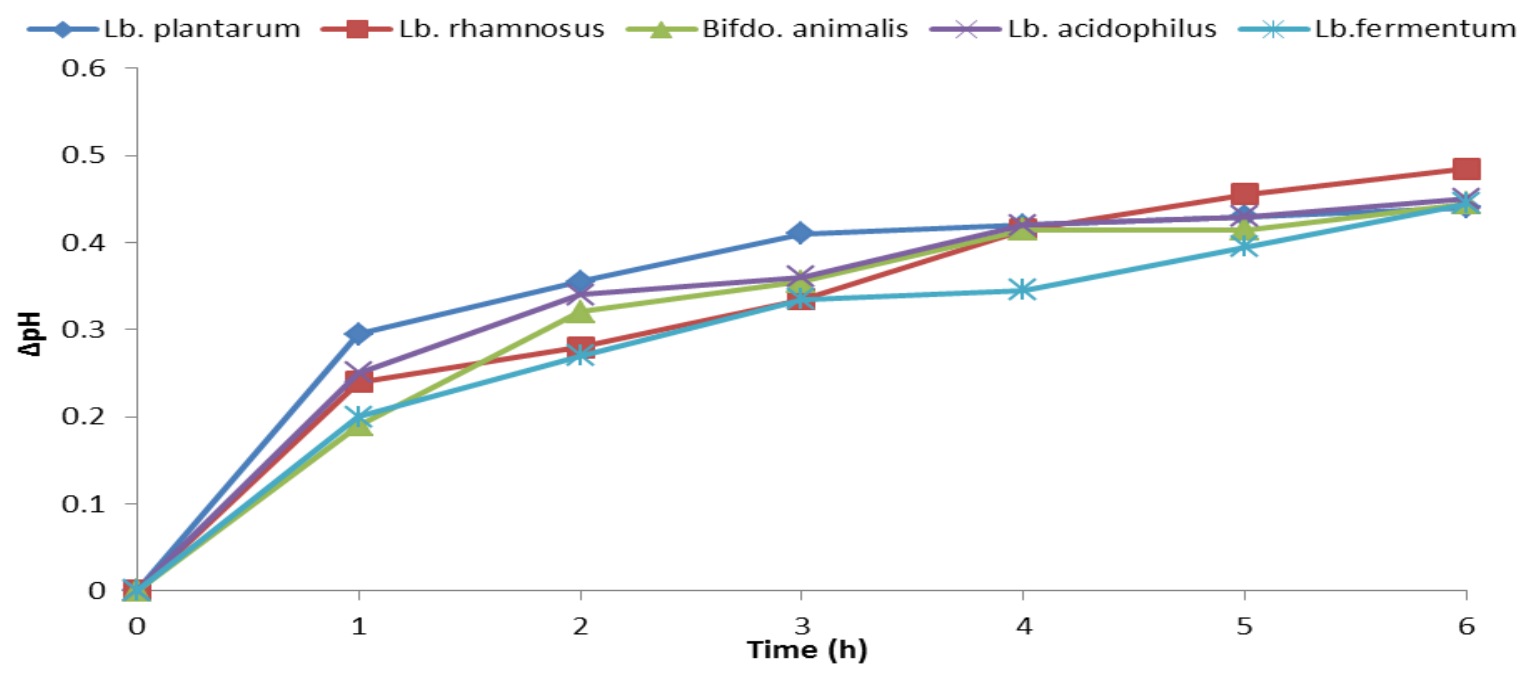

Fig. 1. Acid production of some LAB strains tested in this study

Production of fermented camels' milk like stirred yoghurt.

In the beginning, the LAB isolates were used in the preparation of fermented milk from skim camel milk and compared with traditional starter yogurt. It was found that with the use of LAB isolates in the manufacture of fermented camel milk stirred yoghurt, the time of coagulation was reduced to 6 hours in fermented camel milk stirred yoghurt samples compared to the traditional starter yogurt sample (16 hours). This has been due to the adaptation of these isolates with the nature of the milk source. The chemical composition, microbiological count, $\mathrm{pH}$, and the water holding capacity as well as the viscosity of the product were illustrated in Table .4 and 5. Fermented camel milk products attributes were all similar.

Table 4: Chemical composition of different prepared camels' milk stirred yoghurt

\begin{tabular}{|c|c|c|c|c|c|}
\hline & strains & TS\% & Protein\% & Ash\% & $\mathrm{pH}$ \\
\hline Lb. plantarum & $40 C M$ & $13.21^{\mathrm{d}}$ & $4.51^{\mathrm{e}}$ & 0.910 & $5.74^{\mathrm{a}}$ \\
\hline Lb. fermentum & $17 C M$ & $12.23^{\mathrm{f}}$ & $5.01^{\mathrm{b}}$ & 0.900 & $5.54^{\mathrm{b}}$ \\
\hline Bifi. animalis & $14 C M$ & $12.36^{\mathrm{e}}$ & $4.81^{\mathrm{c}}$ & 0.900 & $5.53^{\mathrm{b}}$ \\
\hline Lb. acidophilus & $31 C M$ & $13.66^{\mathrm{c}}$ & $4.61^{\mathrm{d}}$ & 0.900 & $5.56^{\mathrm{b}}$ \\
\hline Lb. rhamnosus & $25 C M$ & $14.59^{\mathrm{b}}$ & $5.21^{\mathrm{a}}$ & 0.880 & $5.51^{\mathrm{b}}$ \\
\hline Traditional starter & & $15.65^{\mathrm{a}}$ & $4.51^{\mathrm{e}}$ & 0.880 & $4.68^{\mathrm{c}}$ \\
\hline \pm SE & & 0.05 & 0.03 & 0.010 & 0.05 \\
\hline
\end{tabular}

${ }^{\mathrm{a}-\mathrm{f}}$ Means in same column at each parameter with different lowercase letters differed significantly $(\mathrm{p}<0.05)$.

All mean of treatments obtained significant $(\mathrm{P} \leq 0.05)$ differences in total solid, total protein and $\mathrm{pH}$, except ash was not significant $(\mathrm{P}>0.05)$. There was an increase in the TS of the fermented camel milk samples, Lb. rhamnosus 25CM, Lb. plantarum 40CM and $\mathrm{Lb}$. acidophilus 31CM, followed by Bifi. animalis 14CM and Lb. fermentum 17CM, respectively. This increase improved the taste refinement, viscosity and reduced the whey separation. These results were in agreement with those of Salih et al. (2013), who showed that there was an improvement in the viscosity of the yoghurt and reduced the whey separation with the addition of skim milk powder to yoghurt.

Data presented in table (5) shows that there was increasing in the bacterial count in all treatments of the fermented camel milk during $7^{\text {th }}$ day of storage period. This increase can be explained by the sufficient change in the environmental conditions 
Citation: Marwa H. El-Gendy.2018. Influence of probiotic bacteria isolated from camels' milk on the physicochemical properties of camels' milk stirred yoghurt Res. J. Anim. \& Vet. Sci.10 (3): pages: 1-7. DOI: 10.22587/rjavs.2018.10.3.1.

which happen during storage and allow the growth and multiplication of microorganism. After that, the bacterial count in all treatments gradually decreased until $21^{\text {th }}$ of storage due to the lysis of cells during the storage period. It was between 9.51 and $6.24 \log _{10} \mathrm{cfu} / \mathrm{mL}$ during the storage period.

Table 5 shows the bacterial, $\mathrm{pH}$, viscosity, and water retention results during the storage period.

\begin{tabular}{|c|c|c|c|c|c|c|c|c|}
\hline Parameter & & $\begin{array}{c}\text { Lb. } \\
\text { plantarum }\end{array}$ & Lb. fermentum & $\begin{array}{c}\text { Bifi. } \\
\text { animalis }\end{array}$ & $\begin{array}{c}\text { Lb. } \\
\text { acidophilus }\end{array}$ & $\begin{array}{c}\text { Lb. } \\
\text { rhamnosus }\end{array}$ & $\begin{array}{c}\text { Traditional } \\
\text { starter }\end{array}$ & $\pm S E$ \\
\hline & storage & $40 C M$ & $17 C M$ & $14 C M$ & $31 C M$ & $25 C M$ & & \\
\hline \multicolumn{9}{|c|}{ Bacterial count $\log _{10} \mathrm{cfu} / \mathrm{mL}$} \\
\hline & fresh & $9.48^{\mathrm{a}}$ & $9.14^{\mathrm{a}}$ & $9.20^{\mathrm{a}}$ & $9.35^{\mathrm{a}}$ & $9.51^{\mathrm{a}}$ & $7.15^{\mathrm{b}}$ & 0.130 \\
\hline & 7 & $9.54^{\mathrm{ab}}$ & $9.19^{\mathrm{b}}$ & $9.22^{\mathrm{ab}}$ & $9.46^{\mathrm{ab}}$ & $9.63^{\mathrm{a}}$ & $7.22^{c}$ & 0.129 \\
\hline & 14 & $8.67^{\mathrm{ab}}$ & $9.00^{\mathrm{a}}$ & $9.09^{\mathrm{a}}$ & $8.44^{\mathrm{b}}$ & $8.79^{\mathrm{ab}}$ & $7.02^{c}$ & 0.125 \\
\hline & 21 & $8.34^{\mathrm{b}}$ & $8.98^{\mathrm{a}}$ & $9.06^{\mathrm{a}}$ & $8.17^{b}$ & $8.52^{b}$ & $6.24^{\mathrm{c}}$ & 0.130 \\
\hline \multicolumn{9}{|l|}{$\mathrm{pH}$} \\
\hline & fresh & $5.74^{\mathrm{a}}$ & $5.57^{\mathrm{b}}$ & $5.53^{\mathrm{b}}$ & $5.55^{\mathrm{b}}$ & $5.51^{\mathrm{b}}$ & $4.68^{c}$ & 0.023 \\
\hline & 7 & $5.71^{\mathrm{a}}$ & $5.56^{\mathrm{b}}$ & $5.52^{\mathrm{bc}}$ & $5.51^{\mathrm{bc}}$ & $5.45^{\mathrm{c}}$ & $4.59^{\mathrm{d}}$ & 0.025 \\
\hline & 14 & $5.69^{\mathrm{a}}$ & $5.56^{\mathrm{b}}$ & $5.51^{\mathrm{b}}$ & $5.50^{\mathrm{b}}$ & $5.41^{\mathrm{c}}$ & $4.53^{\mathrm{d}}$ & 0.018 \\
\hline & 21 & $5.67^{\mathrm{a}}$ & $5.55^{\mathrm{b}}$ & $5.51^{\mathrm{b}}$ & $5.49^{\mathrm{b}}$ & $5.38^{c}$ & $4.42^{\mathrm{d}}$ & 0.019 \\
\hline \multicolumn{9}{|l|}{ viscosity } \\
\hline & fresh & $15.18^{\mathrm{c}}$ & $5.06^{\mathrm{e}}$ & $5.05^{\mathrm{e}}$ & $10.13^{\mathrm{d}}$ & $17.12^{\mathrm{b}}$ & $20.15^{\mathrm{a}}$ & 0.122 \\
\hline & 7 & $16.58^{\mathrm{c}}$ & $5.63^{e}$ & $5.33^{e}$ & $12.46^{\mathrm{d}}$ & $19.59^{\mathrm{b}}$ & $22.90^{\mathrm{a}}$ & 0.101 \\
\hline & 14 & $16.73^{\mathrm{c}}$ & $5.83^{\mathrm{e}}$ & $5.52^{\mathrm{e}}$ & $13.56^{\mathrm{d}}$ & $20.51^{\mathrm{b}}$ & $23.79^{\mathrm{a}}$ & 0.120 \\
\hline & 21 & $16.99^{c}$ & $6.00^{\mathrm{e}}$ & $5.76^{\mathrm{f}}$ & $14.92^{\mathrm{d}}$ & $21.30^{\mathrm{b}}$ & $24.80^{\mathrm{a}}$ & 0.060 \\
\hline \multicolumn{9}{|l|}{ WHC } \\
\hline & fresh & $28.73^{c}$ & $25.73^{\mathrm{f}}$ & $27.21^{\mathrm{e}}$ & $28.21^{\mathrm{d}}$ & $29.07^{\mathrm{b}}$ & $31.92^{\mathrm{a}}$ & 0.055 \\
\hline & 7 & $27.98^{\mathrm{c}}$ & $25.00^{\mathrm{e}}$ & $26.81^{\mathrm{d}}$ & $27.92^{c}$ & $28.86^{\mathrm{b}}$ & $31.00^{\mathrm{a}}$ & 0.204 \\
\hline & 14 & $27.32^{\mathrm{c}}$ & $24.32^{\mathrm{e}}$ & $25.77^{\mathrm{d}}$ & $27.08^{\mathrm{c}}$ & $28.09^{\mathrm{b}}$ & $30.35^{\mathrm{a}}$ & 0.204 \\
\hline & 21 & $26.73^{\mathrm{e}}$ & $23.73^{\mathrm{d}}$ & $25.21^{\mathrm{c}}$ & $26.82^{b c}$ & $27.50^{\mathrm{b}}$ & $29.87^{\mathrm{a}}$ & 0.195 \\
\hline
\end{tabular}

${ }^{\mathrm{a}-\mathrm{f}}$ Means in same column at each parameter with different lowercase letters differed significantly $(\mathrm{p}<0.05)$.

Significant differences observed within samples during storage days $(\mathrm{P}<0.05)$. In general, bacterial count decreased by $<$ 1.0 logs after 21 days of storage at $4^{\circ} \mathrm{C}$. The best fermented camel milk content has been observed with Lb. rhamnosus $25 \mathrm{CM}$ and then $\mathrm{Lb}$. plantarum 40CM followed Lb. acidophilus 31CM the highest bacterial populations from Bifi. animalis $14 \mathrm{CM}$ and Lb. fermentum 17CM followed by the traditional product. The present results agree with findings by Moslehishad et al. (2013) and Ayyash et al. (2017) who reported that the bacterial viability maintained at $>8.0$ and $>8.5 \log _{10} \mathrm{cfu} / \mathrm{mL}$ in camel milks fermented by Lb. rhamnosus PTCC 1637 and Lb. acidophilus DSM9126, respectively.

There was a gradual decrease in $\mathrm{pH}$ in all treatments during the storage period. This decrease was due to the high level of acidity as a result of initial inoculum $\left(\sim 9.0 \log _{10} \mathrm{cfu} / \mathrm{mL}\right)$. In addition to being the result of fermentation of lactose into lactic acid (Haj et al., 2007 and Fguiri et al., 2016). In general, the decrease in $\mathrm{pH}$ was significant $(\mathrm{P}<0.05)$ in all treatments fermented camel milk during the storage period. Similar findings were found Fguiri et al. (2016) and Ayyash et al. (2017).

Apparent viscosity results of fermented camel milk samples were given in Table 5. Apparent viscosity changes were significantly differences between all treatments fermented camel milk during storage $(\mathrm{P}<0.05)$. Viscosity values increased with all treatments fermented camel milk during storage. The traditional fermented camel milk stirred was obtained at the highest levels of viscosity followed fermented camel milk content $\mathrm{Lb}$. rhamnosus 25CM, Lb. plantarum 40CM and Lb. acidophilus 31CM, respectively. It may be due to the production of EPS (Boosjin et al., 2016), which act both as texturizers and stabilizers as a consequence it was decrease syneresis and improve product stability (Duboc and Mollet , 2001). This resulted was obtained Boosjin et al., (2016), who found The fermented milk texture was not viscous to the required degree when using mesophilic starter culture producing EPS. The present results nearest with findings by Boosjin et al., (2016) in viscosities product Lb. acidophilus stirred yoghurt camel milk. Al-Dhaheri et al. (2017) also found that the use of the Lb. plantarum KX881772 and KX881779 isolated from camel milk have improved cheese properties such as chemical composition, properties, viscous, and sensory characteristics Due to its ability to produce EPS.

Whey separation occurs due to rearrange casein particles in a network of protein as a result of decrease the $\mathrm{pH}$ and temperature used in the manufacturing (Lucey, 2001). Results of water holding capacity (WHC) for all fermented camel milk samples are shown in Table 5. Significant differences were found $(\mathrm{P} \leq 0.05)$ in the WHC $(\%)$ values between stirred yoghurt samples made from camel milk. In general, there was a decrease in WHC in all fermented camel milk samples during the storage period. Also, the mean value of WHC of traditional fermented camel milk- stirred yoghurt was found to be statistically higher than that of all fermented camel milk samples. This may be due to the high TS (Pang et al., 2015) and EPS in fermented camel milk samples. Thus has been affected by viscosity (Vuyst et al. 2003). 
Citation: Marwa H. El-Gendy.2018. Influence of probiotic bacteria isolated from camels' milk on the physicochemical properties of camels' milk stirred yoghurt Res. J. Anim. \& Vet. Sci.10 (3): pages: 1-7. DOI: 10.22587/rjavs.2018.10.3.1.

Since food quality is largely dependent on consumer acceptance, sensory evaluation was conducted as a way to evaluate the characteristics of the natural product and to determine the degree of acceptance in terms of taste, flavor, texture and overall appearance (Sidel and Stone, 1993). The results showed that the strains of Lb. plantarum 40CM, Lb. acidophilus $31 \mathrm{CM}$ and Lb. rhamnosus 25CM gave a clear fermented camels' milk flavor, similar to the yogurt drink like, in terms of flavor and sour. While strains Lb. fermentum 17CM and Bifi. animalis $14 \mathrm{CM}$ were not the flavor or sour clear

\section{CONCLUSION}

In this study, bio-mass, EPS, flavor compounds, proteolytic activity and acidify activity of some strains were evaluated with LAB, which were classified as probiotics bacteria. Then, these strains evaluated when used as starter culture in the manufacture of fermented camels' milk like-stirred yogurt of camels' milk compared to the stirred yogurt of camels' milk produced from the traditional starter culture. Significantly affected microbiological count, $\mathrm{pH}$, viscosity and water holding capacity (\%) of fermented stirred camel milk nonfat yoghurts samples during storage.

It was found that use of $L b$. acidophilus, Lb. plantarum and Lb. rhamnosus were give the closest characters to the stirred yogurt in terms of appearance, viscosity and flavor on Bifi. animalis and Lb. fermentum. Hence, it can be applied as a single starter culture in the fermented milk product industry because of its functional characteristics and high health benefits.

Also, this LAB isolates from camel milk has a high ability to apply probiotics, with high production of EPS, survival at low $\mathrm{pH}$, and in laboratory inhibition of pathogens, which it was make them promising candidates to produce functional food with potential health benefits. The study concluded that LAB isolated from camel's milk. Can be used a starter (single) in the production of stirred fermented milk but prefers to be association with another starter culture.

\section{REFERENCES}

Abdelmoneim, A. H., A. M. Sherif and K. A. Sameh (2016). Rheological Properties of Yoghurt Manufactured by using Different Types of Hydrocolloids. Austin J Nutri Food Sci. 2016; 4(2): 1082.

Abera, T., Y. Legesse, B. Mummed and B. Urga (2016). Bacteriological quality of raw camel milk along the market value chain in Fafen zone, Ethiopian Somali regional state. BMC Res Notes 9:285

Abushelaibi, A., S. Al-Mahadin, K. El-Tarabily, N. P. Shah and Ayyash, M. (2017). Characterization of potential probiotic lactic acid bacteria isolated from camel milk. Lwt-Food Science and Technology, 79, 316-325.

Al-Dhaheri, Ayesha S., Reem Al-Hemeiri, J. Kizhakkayil, A. Al-Nabulsi, Aisha Abushelaibi, Nagendra P. Shah, and M. Ayyash (2017). Health-promoting benefits of low-fat akawi cheese made by exopolysaccharide-producing probiotic Lactobacillus plantarum isolated from camel milk. J. Dairy Sci. 100:1-9

Angmo, K., Anila K. Savitri and T. C. Bhalla (2016). Probiotic characterization of lactic acid bacteria isolated from fermented foods and beverage of ladakh. LWT - Food Science and Technology, 66, 428-435.

Ayad, E. H. E., S. Nashat, N. El-Sadek, H. Metwaly, M. El-Soda (2004). Selection of wild lactic acid bacteria isolated from traditional Egyptian dairy products according to production and technological criteria. Food Microbiology. 21, 715-725

Ayyash, Ayesha M., S. Al-Dhaheri, Suheir Al Mahadin, Jaleel Kizhakkayil, and Aisha Abushelaibi (2017). In vitro investigation of anticancer, antihypertensive, antidiabetic, and antioxidant activities of camel milk fermented with camel milk probiotic: A comparative study with fermented bovine milk. J. Dairy Sci. 101:1-12

Ayyash, M., Aisha Abushelaibi, Suheir Al-Mahadin, M. Enan, K. El-Tarabily and N. Shah (2018). In-vitro investigation into probiotic characterisation of Streptococcus and Enterococcus isolated from camel milk. LWT - Food Science and Technology. 87: 478-487

Barakat, H. and M. F. Y. Hassan (2017). Chemical, Nutritional, Rheological, and Organoleptical Characterizations of Stirred Pumpkin-Yoghurt. Food and Nutrition Sciences, 8, 746-759

Boosjin, Sara N., V. F. Noghani and M. Hashemiravan (2016). Characterization of Probiotic Fermented Milk Prepared by Different Inoculation Size of Mesophilic and Thermophilic Lactic Acid Bacteria. APPLIED FOOD BIOTECHNOLOGY, 3 (4):276-282

Chen, C., S. Zhao, G.i Hao, H. Yu, H. Tian and G. Zhao (2017). Role of lactic acid bacteria on the yogurt flavour: a review. International Journal of Food Properties. S316-S330

de Almeida Júnior, W. L. G., I. da Silva Ferrari, J. V. de Souza, C. D. A. da Silva, M. M.i da Costa and F. S. Dias (2015). Characterization and evaluation of lactic acid bacteria isolated from goat milk. Food Control. 53: 96-103

Duboc, P and B. Mollet (2001). Applications of exopoly-saccharides in the dairy industry, Int. Dairy J.; 11: 759-768

Fguiri, Imen, Manel Ziadi, Moufida Atigui, Naziha Ayeb, Samira Arroum, Mouna Assadi and T. Khorchani (2016). Isolation and characterisation of lactic acid bacteria strains from raw camel milk for potential use in the production of fermented Tunisian dairy products. International Journal of Dairy Technology, 69 (1): 103-113.

Hailu, Y., E. B. Hansen, E. Seifu, M. Eshetu, R. Ipsen, and S. Kappeler. 2016. Functional and technological properties of camel milk proteins: A review. J. Dairy Res. 83:422-429.

Haj, M. H., O. A. El Owni and I. E. M. El Zubeir, (2007). Assessment of chemical and microbiological quality of stirred yoghurt in Khartoum State, Sudan. Research Journal of Animal and Veterinary Sciences, 2, 56-60.

Jumah, R.Y., Skaker, R.R., Abu-Jdayil, B. (2001): Effect of milk source on the rheological properties of yogurt during the gelation process, International Journal of Dairy Technology 54, 89-93. 
Knoshaug E P, Ahlgrent J A and Trempy J E (2000) Growth associated exopolysaccharide expression in Lactococcus lactis subspecies cremoris Ropy352. Journal of Dairy Science, 83: 633-640.

Likotrafiti, Eleni and J. Rhoades (2016). Probiotics, Prebiotics, Synbiotics, and Foodborne Illness. In Probiotics, Prebiotics, and Synbiotics Bioactive Foods in Health Promotion, p. 469-476. Watson, R. R. and V. R. Preedy, Eds. Academic Press. The Boulevard, Langford Lane, Kidlington, Oxford OX5 1GB, UK

Lin, T. H. and T. M. Pan (2017). Characterization of an antimicrobial substance produced by Lactobacillus plantarum NTU 102. Journal of Microbiology, Immunology and Infection. In press. (2017) xx, 1-9 (, http://dx.doi.org/10.1016/j.jmii.2017.08.003 )

Lucey, J. A. (2001). The relationship between rheological parameters and whey separation in milk gels. Food Hydrocolloids, 15(4-6), 603-608.

Mertin p., pochart , P., Flourie, B. , Pellier P., Santos , L ., Desieg, M. 2001 . Effects of chronic ingestion of fermented diary product containing Lactobacillus acidophilus and Bifido- bacterium bifidum on metabolic activates of colonic flora in humans. Am.J. Clin Nutr. 52 :685- 688.

Mohammed, Mariam, Marwa H. El-Gendy, Aida S. Salem and Wafai Z. A. Mikhail (2018). The Effect of Camel Milk Whey Proteins on Lactic Acid Bacteria Isolated From Camel and Cow Milks in Egypt: A Comparative Study. Int. J. Adv. Res. 6(2), 986-998.

Moslehishad, M., M. R. Ehsani, M. Salami, S. Mirdamadi, H. Ezzatpanah, A. N. Naslaji, and A. A. Moosavi-Movahedi. (2013). The comparative assessment of ACE-inhibitory and antioxidant activities of peptide fractions obtained from fermented camel and bovine milk by Lactobacillus rhamnosus PTCC 1637. Int. Dairy J. 29:82-87.

Pang, Z, H. Deeth S. Prakash and N. Bansal (2015). Effect of addition of gelatin on the rheological and microstructural properties of acid milk protein gels. Food Hydrocolloids, 48, 340-351

Parrella A, Caterino E, Cangiano M, Criscuolo E, Russo C, Lavorgna M, Isidori M (2012) Antioxidant properties of different milk fermented with lactic acid bacteria and yeast. Int J Food Sci Technol 47(12): 2493-2502.

Patel, Ami. Nihir Shah and J. B. Prajapati. (2013). Biosynthesis of vitamins and enzymes in fermented foods by lactic acid bacteria and related genera - A promising approach. Croat. J. Food Sci. Technol. 5 (2) 85-91

Rincon-Delgadillo, M. I., A. Lopez-Hernandez, I. Wijaya, and S. A. Rankin (2012). Diacetyl levels and volatile profiles of commercial starter distillates and selected dairy foods. Journal of Dairy Science, 95(3), 1128-1139.

Salazar. N., M. Gueimonde, C.G. de Los Reyes-Gavilán and P. Ruas-Madiedo (2016). Exopolysaccharides Produced by Lactic Acid Bacteria and Bifidobacteria as Fermentable Substrates by the Intestinal Microbiota. Critical Reviews in Food Science and Nutrition, 56:1440-1453

Salih, M. M.and O. I. A. Hamid (2013). Effect of Fortifying Camel's Milk with Skim Milk Powder on the Physicochemical, Microbiological and Sensory Characteristics of Set Yoghurt. Advance Journal of Food Science and Technology 5(6): 765-770

SAS, 2004. SAS / Stat. User's Guide: statistics, system for windows, version 9.1, SAS Inst., Inc. Cary, North Carolina, USA.

Shihata, A. and Sah, N. P. 2000.Proteolytic profiles of yogurt and probiotic bacteria. Intern. Diary .J. 10: 401-408.

Sidel, J.L., and H. Stone (1993). The role of sensory evaluation in the food industry. Food Quality and Preference, 4, 65-73.

Silva, Célia C. G., Sofia P. M. Silva and Susana C. Ribeiro (2018). Application of Bacteriocins and Protective Cultures in Dairy Food Preservation. Front Microbiol. 9: 594

Solieri L, GSRutella and D D Tagliazucchi (2015). Impact of non-starter lactobacilli on release of peptides with angiotensinconverting enzyme inhibitory and antioxidant activities during bovine milk fermentation. Food Microbiol 51:108-116.,

Vuyst, LD, M. Zamfir, F. Mozzi, T. Adrianya, V. Marshall, B. Degeest and F. Vaningelgem (2003). Exopolysaccharide-producing Streptococcus thermophilus strains as functional starter cultures in the production of fermented milks. Int Dairy $\mathbf{J}$ 13:707-717 